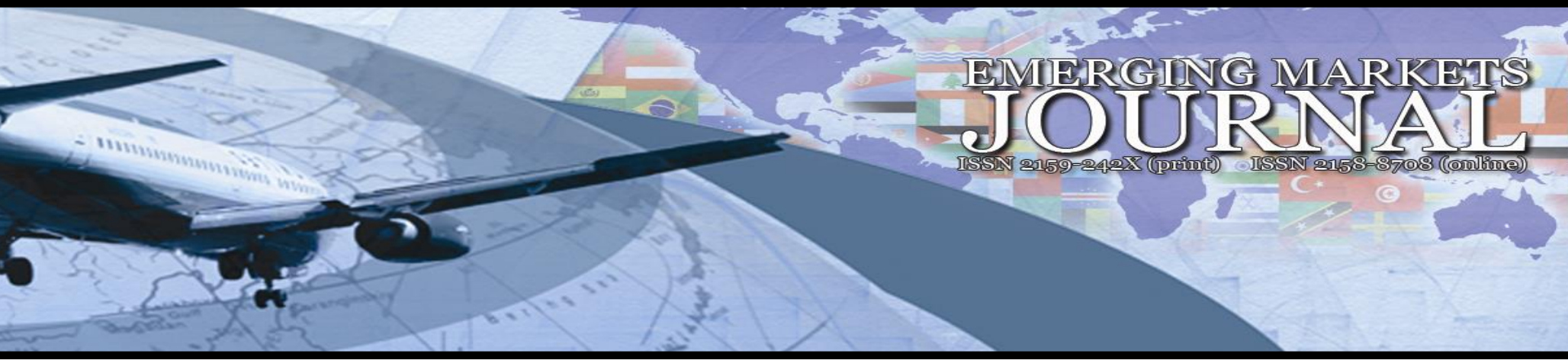

\title{
The Effects of Internal Audit, Audit Committee and Firm Characteristics on Audit Fees in a Multi-Country and Industry Setting
}

\section{Prem Lal Joshi}

ICSSR Institute - Western Regional Centre, India | e-mail: prem@acadjoshi.com

\section{Ashutosh Deshmukh}

Black School of Business - Penn State Behrend , USA | e-mail: avd1@ psu.edu

\section{Jamel Azibi}

University of Jendouba, Tunisia | e-mail: jamel.az1@gmail.com

Volume 11 No 2 (2021) ｜ ISSN 2158-8708 (online) ｜ DOI 10.5195/emaj.2021.231 | http://emaj.pitt.edu

\begin{abstract}
This paper examines the association between audit fees and attributes of internal audit (IA), audit committee (AC), as measured by independence and financial expertise, as well as characteristics of the firm. The determinants of audit fees have been extensively investigated in the prior literature, but the results are conflicting. We develop a comprehensive model from a multi-country and multi-industry perspective. A total of 3,136 companies covering a period of 10 years (2011-2020) with 15,247 observations from 55 countries were included in this study. We found that the most critical variables that have a significant positive effect on the audit fees are client size, leverage (risk), profitability, complexity, losses, AC independence, AC expertise and auditor size. The study also shows that audit pricing is significantly negatively related to foreign operations, auditor tenure, and internal audit independence. The results highlight variables that affect audit fees across a range of countries/industries.
\end{abstract}

Keywords: Audit Fee, Audit Board, Audit Committee, Internal Audit Independence, Auditor Rotation

\section{(c) $\mathrm{EY}$}

New articles in this journal are licensed under a Creative Commons Attribution 3.0 United States License.

\section{ULIS $\underline{D-S \text { Sork }}$}

This journal is published by the University Library System of the University of Pittsburgh as part of its D-Scribe Digital Publishing Program, and is cosponsored by the University of Pittsburgh Press. 


\section{The Effects of Internal Audit, Audit Committee and Firm Characteristics on Audit Fees in a Multi-Country and Industry Setting}

\author{
Prem Lal Joshi \\ Ashutosh Deshmukh \\ Jamel Azibi
}

\section{Introduction}

This paper examines the association between audit fees and attributes of internal audit (IA), audit committee (AC), measured by independence and financial expertise, as well as characteristics of the firm. We investigate this issue from a multi-country and multiindustry perspective, probing for variables that consistently affect audit fees across such a diverse landscape. The seminal paper by Simunic (1980) initiated the examination of the factors that influence audit fees. The empirical evidence related to the effects that the attributes of IA, AC and firm characteristics on audit fees are still inconclusive at the global level. We further explore this area to provide incremental evidence.

Being a part of the corporate governance process, IA and AC together mitigate the problems related to the quality of information. IA makes it easier for the external auditors to assess the internal control system, the inherent risk and the regulatory compliance. Thus, possibly resulting in a reduction of substantive tests (Felix et al., 2001). Additionally, AC attempts to mitigate agency problems by ensuring quality financial reporting to principals. Does this affect audit fees?

The auditing literature contains a wealth of research on audit fees. Earlier studies on the variables influencing audit pricing were focused on the presence of an AC and IA in the organizations. Recent studies have examined the association between IA, AC and firm characteristics with audit fees. However, the empirical results in these studies are mixed and conflicting. There still exists a research gap. Furthermore, the relationships are not constant and vary depending on external factors such as the economy, regulations and country. As such, there is a need to complement the previous findings with a broader study. Given the continuously evolving role of corporate governance mechanisms such as IA and AC, the continued investigation of their influence on audit fees should be still relevant, the only question being to what extent.

So, we pose the following research question: Do attributes of IA, AC and firm characteristics influence the amount and scale of audit fees charged by the external auditors? If yes, what variables are significant across a range of industries and countries?
The rest of the paper is divided into five sections. Section II provides a comprehensive prior literature review and identifies the different results. This literature review then informs our hypotheses development. Section III develops a theoretical framework and estimation model. Section IV describes the sources of data and the detailed methodology used in this paper. Section V covers results and discussion. Finally, Section V is the Conclusion. It concludes the study findings and provides implications of our results as well as directions for future research.

\section{Literature Review and Hypotheses Formulation}

Audit Fees

The fees charged by the external auditors depend on a myriad of considerations. Agoes (2004) states: "The amount of the charge depends on, among others, the risk of the assignment, the complexity of the services provided, the level of expertise required to carry out the services of proficiency level, the cost structure of the firm concerned and other professional considerations". Simunic (1980) developed a model that investigated the determinants of audit fees. Consequently, there was an explosion of research. Consistent with this prior research (Choi, et al, 2010; Hallak and Silva, 2012; Yatim et al., 2006), we measure the dependent variable as the natural logarithm of audit fees.

\section{Audit Board/Audit Committee}

The paper treats the terms audit board and audit committee synonymously (AC). The existence and influence of ACs affect audit fees. Lee and Mande's (2005) study suggests that effective ACs positively influence the level of audit coverage. Goodwin-Stewart and Kent (2006) argue that AC members have incentives to minimize the litigation risk and reputation loss, say due to fraudulent financial reporting, as such, they insist on quality audits, which may cost more. They also report a positive association between audit fees and the existence of AC, while Dinh (2012) reports a negative relationship. Also, Wu (2012) finds a significant negative relationship between audit fees and corporate governance mechanisms. On the other hand, Rainsbury et al. (2009) report that $\mathrm{AC}$ existence and audit fees are not related. Thus, the prior findings are mixed, though more studies support a positive relationship between $\mathrm{AC}$ and audit fees. We hypothesize:

H1: The existence of an AC is positively related to audit fees

\section{Audit Committee Expertise}

ACs having financial expertise, do support high-quality financial statements (Burrowes and Hendriks, 2005). A financial expert in AC can result in a rigorous review of the IA. Goodwin-Stewart and Kent's (2006) results show that if the AC consists of at least one financial expert then it significantly, positively affects audit fees. Ghafran (2017) and Harris's (2007) studies provide similar results. Additionally, Bala et al.'s (2018) 
study reveals that AC financial expertise is a significant positive factor in determining the amount of audit fees in Nigeria. On the contrary, Azmi et al. (2013), in the Malaysian context, find exact opposite results, that is, financial expertise is negatively related to the amount of audit fees. Interestingly, Haniffa and Cooke (2002) find that $\mathrm{AC}$ attributes do not influence audit fees in Malaysia. Thus, prior studies have conflicting findings but more studies support a positive relationship between AC financial expertise and audit fees. Therefore, we hypothesize:

$\mathbf{H}_{2}$ : The higher level of financial expertise of $\mathrm{AC}$ members is positively related to higher audit fees

\section{Non-executive Member (Independence of Audit Committee)}

An AC is strengthened by independent, nonexecutive directors who bring an independent mindset to their role. Sarbanes Oxley Act - SOX (2002) also recommends the independence of AC members. Kikhia (2015) posits that an independent AC evaluates corporate affairs without bias and monitors management more effectively. Carcello et al. (2002) and Yatim et al. (2006) find that ACs that are independent, have financial expertise, and are diligent result in higher audit fees. Similarly, Abbor et al.'s (2003) study shows that ACs that have more outside directors, that is, are more independent are associated with higher audit fees. Recently, Al-Hajaya (2019) reported a similar result for the Jordanian companies. The author also reported such companies hire Big4 firms to signal their commitment to audit quality. On the other hand, Kanakriyah (2020) and Kikhia (2015) find no relationship between AC independence and audit fees. However, the preponderance of the evidence indicates that a relationship between $\mathrm{AC}$ independence and audit fees exists. So, we hypothesize:

H3: Non-executive members on AC are positively related to audit fees

\section{Auditor's Tenure}

The auditor's tenure is related to auditor independence and can affect audit fees. SOX (2002) contends that if the auditors conduct the audit for four or more years, they should not be considered independent. Beshkooh et al. (2003) find that optimal tenure for an auditor is one to three years from an audit effectiveness viewpoint. Warrad (2008) reports that audit partner tenure significantly explains audit fees for Jordanian companies. In the South Korean context, Kwon et al. (2014) show that audit fees increased after the auditor rotation. Silva et al.'s (2020) study shows that auditor rotation strongly influences audit fees. Castro et al. (2015) point out that large Brazilian companies lowered audit fees by changing auditors. Malagila et al.'s (2020) study also finds a positive relationship between longer audit tenure and lower audit fees. However, Urhoghide and Izedonmi (2015) reported a significant positive relationship between auditor tenure and audit fees for Nigerian companies. Also, Kikhia (2015) found no relationship between audit tenure and audit fees in China and Jordan.
The majority of the studies point to a significant and negative relationship between audit tenure and audit fees. Thus, we hypothesize:

H4: Auditor tenure and audit fees are negatively related

Independence of Internal Audit Function (IAF)

According to Sierra-Garcia (2019): "A fundamental aspect to assess the independence of the IA is the status of this function within the organization and who determines its functions, who monitors its activity and who the IA must report to". The IAF variable is measured as a binary variable based on the placement of the IAF in the organizational hierarchy. When IAF is independent, Scheneider (1985) reports that the external auditors rely more on IAF and reduce audit work. Alzeban and Sawan (2015) argue that a good relationship between the AC and the IAF may strengthen corporate control. This may lead the external auditor to rely more on internal controls. Felix et al.'s (2001) study indicated that the higher contribution of IA to external audit reduces audit fees. Zaman and Sarens (2013) also report similar results. Recently, Sierra-Garcia et al. (2019) reported a positive relationship between the independence of IAF and audit fees. Given the results, we hypothesize:

Hs: There is a negative relationship between independent IAF and audit fees

\section{Size of External Auditor}

Haniffa and Cooke (2002) and DeAngelo (1981) find that large auditing firms (Big4) can charge higher fees relative to small auditing firms. Fafatas and Sun (2010) report that Big4 auditors who are dominant in the country can charge approximately $27 \%$ more fees compared to the competitor firms, after controlling for all other variables. Similarly, Castro et al. (2015) and VulHag and Leghari (2015) report a positive relationship between audit fees and Big4 audit firms. Choi et al.'s (2010) study results show that in the Chinese market, audit firm size results in higher audit quality and audit fees. Tran et al.'s (2019) study finds that the bigger the size and the better the experiences of the firms and auditors, the higher the audit fee.

Big4 audit firms are reputed and provide quality audit services. El-Gammal (2012) and Choi et al. (2010) contend that corporations signal higher quality audits by using Big4 and paying an additional premium. However, Naser and Hasan (2016) find that the status/reputation of the audit firm and audit fees are not related. Since the majority of prior studies provide evidence that external auditors' reputation or status impacts audit fees, we hypothesize:

H6: The presence of Big4 auditors has a positive relationship with audit fees

\section{Size of the Firm}

The firm size can be measured using a variety of measures such as the average of total assets, total sales, sales growth, inventories, debt, liabilities or receivables. In the case of large firms, to form an audit opinion, more audit work/procedures are required. Given 
the higher audit work, the higher audit fee is expected. Many studies (Silva et al, 2020; Liu, 2017; Ali and Aulia, 2015; Castro et al., 2015; Dinh, 2012; Galani et al., 2011) have shown that firm size has a positive and significant relationship with audit fees. Therefore, we hypothesize:

$\mathbf{H}_{7}$ : The firm size (log of the average of total assets) is positively related to audit fees

\section{Profitability (ROA)}

Prior research indicates a positive relationship between audit fees and profitability (Dekeyser et al., 2019; Joshi and Al-Bastaki, 2000; Simunic, 1980). On the other hand, a few studies (Hossain, and Sobhan, 2019; Naser and Hassan, 2016; Ling, 2014) show that profitability and audit fees are not related. While Barua et al. (2019) and Ittonen and Peni (2012) report an interesting result that external auditors will increase the audit fees even if the auditee is making losses. Other evidence (Kanakriyah, 2020; Velte and Loy, 2018; Urhoghide and Izedonmi, 2015) indicates a negative relationship between profitability and audit fees. However, it seems logical that highly profitable companies will pay higher audit fees. Hence, we hypothesize:

Hs: Profitability of the auditees positively influences audit fees

Leverage (financial risk)

$\mathrm{Wu}$ (2012) measures the leverage variable as total debt divided by the average of total assets, so do we. Higher debt loads indicate higher financial risk and more audit work resulting in higher audit fees (Haque et al., 2019; Prawitt et al., 2011; Messier et al., 2011). On the other hand, a few studies (see, Kikhia, 2015; Hallak and Silva, 2012; Naser and Nuseibeh, 2008) report a significant negative association between leverage and audit fees. Naser and Hassan (2016), on the other hand, report that audit fee is not significantly associated with companies' risk. The results are conflicting, but the majority of the studies support a positive relationship between leverage and audit fees. So, we hypothesize:

H9: Leverage (financial risk) has a positive relationship with audit fees

Losses

We can reason that a loss-making company's risk is higher and the firm is likely to pay a higher amount of audit fees. Zaman et al. (2011) suggest that when an auditee's business risk is higher than the acceptable level, audit fees include a premium. Since a loss-making firm has a higher level of risk, we can expect a positive association between losses and audit fees. In this situation, we hypothesize:

$\mathbf{H}_{10}$ : Higher losses are positively related to audit fees

Complexity

Prior studies indicate that the complexity of the company can affect audit fees. Generally, this variable is measured as the sum of stocks and debtors divided by the average of total assets (Ho and Hutchinson, 2010). The increase in the firm complexity often results in a higher level of difficulty in auditing the client (Haceknbrack and Knechel, 1997; Simunic, 1980). The majority of studies (Silva et al., 2020, Januarty et al., 2019, Urhoghice and Izedonmi, 2015; Ho and Hutchinson, 2010) can be mentioned at this point. There are few studies, for example, Naser and Hassan (2016) that indicate a negative effect of firm complexity on audit fees. Given the evidence, we hypothesize:

\section{$\mathbf{H}_{11}$ : Firm complexity is positively related to audit fees}

\section{Foreign Operations}

Joshi et al. (2000) posited that complex, diversified businesses with foreign operations required more audit resources. A higher number of foreign subsidiaries results in more audit work and thereby in higher audit fees. Sandra et al. (1996) stated that "Auditors of group companies, with a number of subsidiaries/branches, often incur high costs in examining the individual financial statements and in assessing the accuracy of consolidated financial statements". On the contrary, Hoffman et al. (2018) show a negative relationship between foreign transactions and audit fees. Since the majority of prior studies have a positive association between foreign operations and audit fees, we hypothesize:

$\mathbf{H}_{12}$ : The existence of foreign operations is positively related to audit fees

In summary, the literature paints a rather complex picture. A range of studies conducted in developed and developing countries, different time settings and different methodologies presents conflicting and inconclusive evidence. As the economic, regulatory and capital market influences change, the findings in this area will also evolve and change. However, the research interest in IA, AC and firm performance will remain intense as these are essential mechanisms of corporate governance. The area certainly needs revisiting and the investigation of factors that affect audit fees should be periodically re-evaluated.

\section{Theoretical Framework and Estimation Model}

The estimation model is provided below:

$$
\begin{array}{r}
Y=a_{0}+\beta_{1} X_{1}+\beta_{2} X_{2}+\beta_{3} X_{3}+\beta_{4} X_{4}+\beta_{5} X_{5}+\beta_{6} X_{6}+ \\
\beta_{7} X_{7}+\beta_{8} X_{8}+\beta_{9} X_{9}+\beta_{10} X_{10}+\beta_{11} X_{11}+\beta_{12} X_{12}+\varepsilon
\end{array}
$$

\section{Dependent Variable:}

$Y=$ Audit fees ${ }^{1}$ paid to external auditors (Natural log of total fees paid to external auditors)

\footnotetext{
${ }^{1}$ Eikon database defines audit fees as fees for services that are reasonably related to the performance of the audit or review of the company's financial statements.
} 


\section{Explanatory Variables:}

$\mathrm{X}_{1}=$ Audit board (if yes $=1$ otherwise 0 , existence)

$\mathrm{X}_{2}=$ Audit committee expertise (under SOX requirements)

$\mathrm{X}_{3}=$ Percentage of Non-executive members

$\mathrm{X}_{4}=$ Auditor tenure: The number of years current auditor is serving the organization

$\mathrm{X}_{5}=$ Internal audit independence (based on Eikon scores)

$\mathrm{X}_{6}=$ Size of auditor $(\mathrm{Big} 4=1$, otherwise $=0)$

$\mathrm{X}_{7}=$ Profitability (return on assets)

$\mathrm{X}_{8}=$ Firm size (log of average of total assets)

$\mathrm{X}_{9}=$ Leverage (long-term debts / average of total assets)

$\mathrm{X}_{10}=$ Losses (if the firm incurred losses in the previous financial year $=1$; otherwise $=0$ )

$\mathrm{X}_{11}=$ Complexity (stocks and receivables / average of total of assets)

$\mathrm{X}_{12}=$ Foreign operations $($ if yes $=1$, otherwise $=0$ )

\section{Data and Methodology}

Data

The data were extracted from Thomson Reuters Asset 4, all data are in US dollars. All firms covered by Thomson Reuters Asset 4 from 2011 to 2020 were considered. Table 1a, Table $1 \mathrm{~b}$ and Table 1c summarize the sample selection process.

Table 1a: Sample Selection

\begin{tabular}{|c|c|}
\hline & SAMPLE \\
\hline $\begin{array}{l}\text { Observations for all firms in the Eikon database } \\
\text { and in Asset } 4 \text { from } 2011 \text { through } 2020\end{array}$ & 95,610 \\
\hline $\begin{array}{l}\text { Observations dropped and the reason for } \\
\text { dropping }\end{array}$ & 66,249 \\
\hline $\begin{array}{l}\text { OBSERVATION WITHOUT INTERNAL } \\
\text { AUDTING REPORTING }\end{array}$ & 14,114 \\
\hline Final sample & $\begin{array}{l}\text { Period of study - 2011-2020 } \\
\text { Firms - } 3136 \\
\text { Countries - } 55\end{array}$ \\
\hline
\end{tabular}

Source: Authors' own compilation

The final sample includes 15,247 firm-year observations (3136 unique firms) from 55 countries. Panel B presents the distribution of observations across Global Industry Classification Standards (GICS https://www.msci.com/gics) per industries and years. Consumer Discretionary (1817), Industrial (2571) and Financials (2722) have the highest number of observations.

\section{Table 1b: Samples by Industrial Sectors}

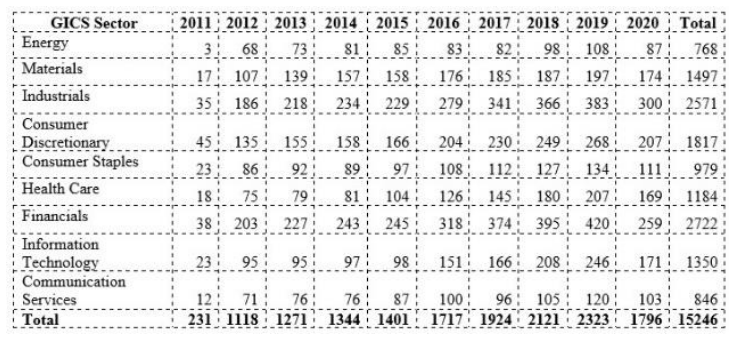

Source: Authors' own compilation
Panel C indicates that the United States has the largest number of observations (6961) followed by Canada (1276), the United Kingdom (1,219), Australia $(1,053)$, Japan (934) and Germany (518).

\section{Table 1c: Number of Observations by Country}

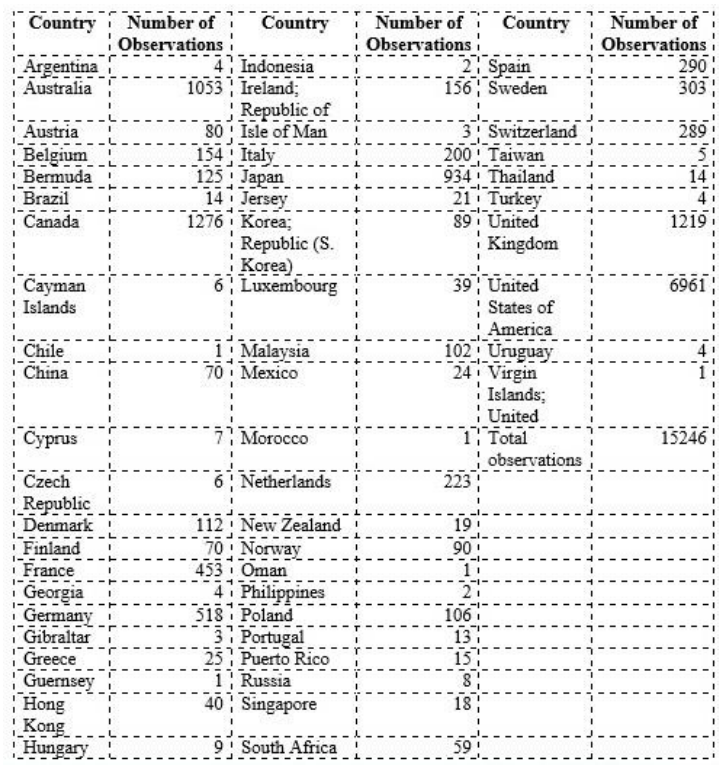

Source: Authors' own compilation

We restrict the analysis to publicly listed companies that follow recommendations of the SarbanesOxley $\mathrm{Act}^{2}$. We believed that considering only these firms would increase the reliability of the analysis. The sample selection starts with 29,361 firm-year observations with available data on audit fees, internal reporting and firm characteristics. We deleted 14,114 observations due to missing internal auditing reporting and other issues.

\section{Results and Discussion}

Results

Data were analyzed using STATISTICA Software 15.

\section{Table 2: Descriptive Statistics}

\begin{tabular}{|l|r|r|r|r|}
\hline & $\begin{array}{c}\text { No of } \\
\text { observations }\end{array}$ & \multicolumn{1}{c|}{ Mean } & $\begin{array}{c}\text { Standard } \\
\text { Deviation }\end{array}$ & \multicolumn{1}{|c|}{ Skewness } \\
\hline Audit Fees & 15247 & 12.31307 & 1.728304 & -.0788652 \\
\hline Audit Board & 15247 & .9675346 & .1772384 & -5.275943 \\
\hline AC Expertise & 15247 & .8534138 & .3537045 & -1.998421 \\
\hline \% of Non-exc. Members & 15247 & .9303726 & .1962814 & -3.764979 \\
\hline Auditor Tenure & 15247 & 9.46842 & 7.058871 & .5943749 \\
\hline IA Independence & 15247 & 57.26001 & 8.131097 & 2.030267 \\
\hline Auditor Size & 15247 & .7583131 & .4281196 & -1.206773 \\
\hline Profitability & 15247 & 22.87541 & 1.751032 & .3761425 \\
\hline Firm Size & 15246 & .2257918 & .1925601 & 2.506845 \\
\hline Leverage & 15246 & .1265167 & .3324417 & 2.246984 \\
\hline Losses & 15247 & -2.262705 & 1.394055 & -.6760882 \\
\hline Complexity & 15247 & .1470453 & .3541627 & 1.993244 \\
\hline Foreign Op.s & 15247 & 12.31307 & 1.728304 & -.0788652 \\
\hline
\end{tabular}

Source: STATISTICA Software 15 Output

\footnotetext{
2 For example, does the company have an audit committee with at least three members and at least one "financial expert" within the meaning of SarbanesOxley?
} 
Table 2 presents the descriptive statistics such as the number of observations, mean and standard deviation and skewness for the dependent and independent variables. The value of standard deviation is much below the mean value for most of the variables. The total number of observations included for analysis is 15,247 .

The results of the descriptive analysis indicate that audit fee paid by the companies range from a minimum of (log of audit fees) 5,011 to 20.05. The firm size is measured by the natural logarithm of the company's average of total assets with a mean value of 0.2257918 . Profitability (ROA) has a mean of 22.8754 . Additionally, leverage (financial risk) as a variable shows a mean value of 0.1265167 . The mean value for the complexity of the companies is 0.1470453 . The mean value for losses incurred by companies is -2.262705 . Also, $75.83 \%$ of companies are audited by Big4 audit firms.

Table 3 presents a correlation matrix among dependent and independent variables. A perusal of all correlation values shows that there is a moderately high correlation (0.81) between "Percentage of Non-executive Members" and "Audit Board". This is expected and not very serious as no multicollinearity problems are indicated by the later analysis.

\section{Table 3: Correlation Matrix}

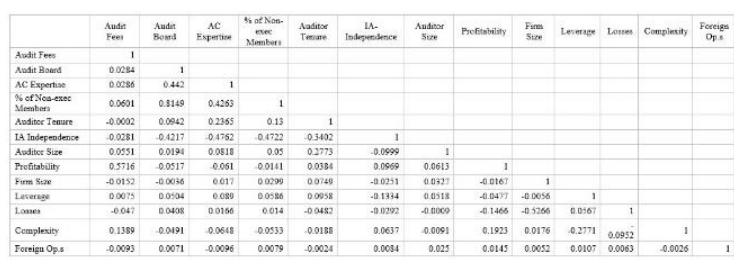

Source: STATISTICA Software 15 Output

Table 4 presents the results of regression analysis. The dependent variable is audit fees and the twelve independent variables are corporate governance (audit board/committee, AC expertise, non-executive members), internal audit (independence of internal audit), external auditor (auditor size, auditor rotation), and firm characteristics (size, financial risk, complexity, profitability, and foreign operations). The results of the regression model in terms of standardized coefficients (Beta), t-values, and significant levels are presented in this table.

Table 4: Regression Results

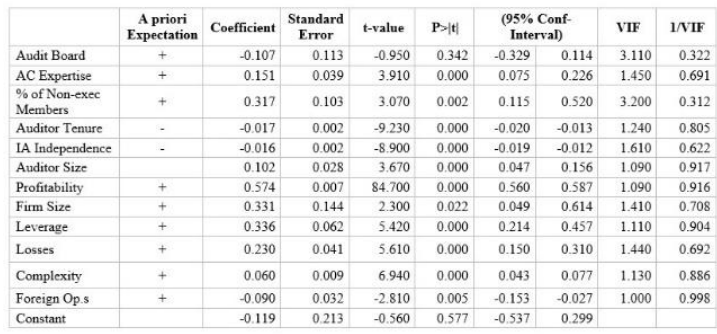

Source: STATISTICA Software 15 Output
Method: Ordinary Least Square (OLS)

Number of observations $=15,246$

F- value $(12,15233)=663.59$

Prob $>\mathrm{F}=0.0000$

$\mathrm{R}^{2}=0.3433$

Adj. $R^{2}=0.3428$

The F- value $(12,15233=663.59)$ supports the significance of the regression at 0.01 level. The R-value is 0.3433 , and the adjusted $\mathrm{R}$ square value is $34.28 \%$. The explanatory power of the model, as expressed by adjusted $\mathrm{R}$ square, indicates that $34.28 \%$ of the variations in the dependent variable (audit fees) can be explained by the variation in independent variables. F-ratio is 7.658 and is significant at 0.01 level.

We also investigated the problem of multicollinearity by examining tolerance value and variance inflation factor (VIF). Table 4 also presents the VIF values for the regression equation when all independent variables are present in the equation. Using criteria given by Judge et al. (1985), the correlation between "Percentage of Non-executive Members" and "Audit Board" does not appear to be a serious issue. We conclude that multicollinearity problems are minimal.

\section{Discussion}

Table 5 presents the results of the hypotheses testing. In summary, out of the 12 hypotheses tested in the model, 10 are supported. The detailed discussions follow.

Table 5: Testing for Hypotheses

\begin{tabular}{|c|c|c|c|}
\hline \# & Hypothesis & Supported & $\begin{array}{c}\text { Not } \\
\text { Supported }\end{array}$ \\
\hline $\mathrm{H}_{1}$ : & $\begin{array}{l}\text { The existence of an } \\
\text { AC is positively } \\
\text { related to audit fees. }\end{array}$ & & $\sqrt{ }$ \\
\hline $\mathrm{H}_{2}$ : & $\begin{array}{l}\text { The higher level of } \\
\text { financial expertise of } \\
\text { AC members is } \\
\text { positively related to } \\
\text { higher audit fees. }\end{array}$ & $\sqrt{ }$ & \\
\hline $\mathrm{H}_{3}:$ & $\begin{array}{l}\text { Non-executive } \\
\text { members on AC are } \\
\text { positively related to } \\
\text { audit fees. }\end{array}$ & $\sqrt{ }$ & \\
\hline $\mathrm{H}_{4}:$ & $\begin{array}{l}\text { Auditors' tenure and } \\
\text { audit fees are } \\
\text { negatively related. }\end{array}$ & $\sqrt{ }$ & \\
\hline $\mathrm{H}_{5}:$ & $\begin{array}{l}\text { There is a negative } \\
\text { relationship between } \\
\text { independent IAF and } \\
\text { audit fees. }\end{array}$ & $\sqrt{ }$ & \\
\hline $\mathrm{H}_{6}:$ & $\begin{array}{l}\text { The presence of Big4 } \\
\text { auditors has a positive } \\
\text { relationship with audit } \\
\text { fees. }\end{array}$ & $\sqrt{ }$ & \\
\hline $\mathrm{H}_{7}:$ & $\begin{array}{l}\text { The firm size (log } \\
\text { of the average of } \\
\text { total assets) is } \\
\text { positively related } \\
\text { to audit fees. }\end{array}$ & $\sqrt{ }$ & \\
\hline
\end{tabular}

The Effects of Internal Audit, Audit Committee and Firm Characteristics on Audit Fees in a Multi-Country and Industry Setting 


\begin{tabular}{|l|l|c|c|}
\hline $\mathrm{H}_{8}:$ & $\begin{array}{l}\text { The profitability of the } \\
\text { auditees positively } \\
\text { influences audit fees. }\end{array}$ & $\sqrt{ }$ & \\
\hline $\mathrm{H}_{9}:$ & $\begin{array}{l}\text { Leverage (financial } \\
\text { risk) has a positive } \\
\text { relationship with audit } \\
\text { pricing. }\end{array}$ & $\sqrt{ }$ & \\
\hline $\mathrm{H}_{10}:$ & $\begin{array}{l}\text { Higher losses are } \\
\text { positively related with } \\
\text { audit fees. }\end{array}$ & $\sqrt{ }$ & \\
\hline $\mathrm{H}_{11}:$ & $\begin{array}{l}\text { Firm complexity is } \\
\text { positively related with } \\
\text { audit fees. }\end{array}$ & $\sqrt{ }$ & \\
\hline $\mathrm{H}_{12}:$ & $\begin{array}{l}\text { The existence of } \\
\text { foreign operations is } \\
\text { positively related to } \\
\text { audit fees. }\end{array}$ & & \\
\hline
\end{tabular}

Source: STATISTICA Software 15 Output

Hypothesis 1 (Audit Board/Committee) predicts a negative but insignificant relationship with audit fees $(\mathrm{t}=-0.95 ; \mathrm{P}>0.05)$. This is in line with $\mathrm{Wu}$ (2012) reporting a negative relationship between corporate governance and audit fees. Sobrinho (2016) also found that better governance practices reduce legal risks and the auditors then reduce audit fees. Additionally, Collier and Gregory (1996) argued that "From the supply side, the audit committee's existence strengthens internal controls which may lead the external auditor to reduce the assessed level of control risk and charge lower audit fee." These arguments seem to hold across a broad swathe of industries and countries, given our results.

Hypothesis 2 (Audit Committee Expertise) reveals a positive and significant relationship between audit committee expertise and audit fees ( $\mathrm{t}=3.91$; $\mathrm{p}<0.01$ ). This result strongly supports previous findings (Mustapha et al., 2020; Ghafran and O'Sullivan, 2017; Goodwin-Stewart and Kent, 2006). This implies that AC members across the countries represented in our sample demand high-quality audits from the auditor, thereby increasing the audit efforts and time commitment that subsequently results in higher audit fees.

Hypothesis 3 (Percentage of Non- executive Members) predicts that the percentage of non-executive members on $\mathrm{AC}$, which is an indicator of $\mathrm{AC}$ independence, is positively related to audit fees. The results $(\mathrm{t}=3.07 ; \mathrm{p}<0.01)$ indicate a significant positive effect on audit fees. This is in line with prior studies (Olushola et al., 2020; Al Hajaya, 2019; Rainsbury, 2009; Harris, 2007; Yatim et al., 2006, Abbott et al., 2003). These studies indicated that independence in AC is related to higher audit fees. This is important, since the percentage of non-executive members seem to make the audit board independent (or at least the perception) across a range of industries and countries.

Hypothesis 4 (Auditor Tenure) indicates a strong negative and significant relationship between auditor size and audit fees $(\mathrm{t}=-9.23 ; \mathrm{p}<0.01)$. This result strongly supports previous findings (Malagila et al. 2020; Castro et al., 2015; Urhoghide and Izedonmi, 2015; Köhler and Ratzinger-Sakel, 2012). As audit tenure increases the resulting efficiencies negatively affect audit fees. Eight previous studies reported a significant negative relationship between audit tenure and audit fees (Hay et al., 2006). Our results support those studies.
Hypothesis 5 (Internal Audit Independence) predicts a negative but significant relationship with audit fees, as supported by our analysis $(t=-8.90 ; p<0.01)$. An independent internal audit function can strengthen a range of monitoring, governance and risk management activities generally broader in scope than the external audit (Carey et al., 2000). Such extra assurance may result in reduced audit fees. The results in the literature primarily support such assertion. Our results indicate that such results are common across a range of industries and even across cultures, that is, countries.

Hypothesis 6 (Auditor Size) indicates a positive and significant relationship between auditor size and audit fees $(\mathrm{t}=3.67 ; \mathrm{p}<0.01)$. Our result strongly supports previous findings (Kanakriyah, 2020; Naser and Hassan, 2016). Big4 audit firms are large and provide higher quality audit services to their clients and do charge premium audit fees. This perception is reinforced by our results.

Hypothesis 7 (Firm Size) predicts a strong positive and significant relationship with audit fees $(\mathrm{t}=$ $84.70 ; \mathrm{p}<0.05)$. Our finding supports the previous research (Hossain and Sobhan, 2019; Wu, 2018; Januarti and Wiryaningrum, 2018; Nasser and Hassan, 2016; Urhoghide and Izedonmi, 2015). Firm size indicates larger revenues, national and multinational operations, and complex product lines, among other things, which are reflected in higher audit fees.

Hypothesis 8 (Profitability) predicts that influences audit fees. A positive and significant association between ROA and the audit pricing $(t=2.30$; $\mathrm{p}<0.01)$ is discovered. Prior literature review shows mixed findings. Though, the majority of the studies indicate that ROA is positively related to audit fees (Dekeyser et al., 2019; Hasan, 2017; Andriyani and Laksito, 2017; Joshi and Al-Bastaki, 2000; Sandra and Patrick, 1996). Our results indicate that such findings hold across a wide range of industries and countries.

Hypothesis 9 (Leverage) predicts that leverage has a positive relationship with audit fees. The results indicate a strong positive influence of leverage on audit fees $(\mathrm{t}=5.42 ; \mathrm{p}<0.01)$. Obviously, the higher the risk premium due to financial problems and litigation, the higher the audit fees. Furthermore, often loan agreements include covenants, and firms are expected to comply with such covenants. For example, financial data presented in financial statements to be audited by the 'Big4' audit firms and a certain level of financial ratios should be maintained, among other things, can be the requirements for loans. Thus, our results seem logical.

Hypothesis 10 (Losses) predicts a positive and significant relationship between losses and audit fees $(\mathrm{t}=5.61 ; \mathrm{p}<.001) . \mathrm{Wu}$ (2012), Hay (2006) and Simunic (1980) had similar results. Generally, firm losses as an indicator of risk have been studied in very few papers. We did find a positive association between losses and audit fees.

Hypothesis 11 (Complexity) predicts a positive and significant relationship between complexity and audit pricing $(\mathrm{t}=6.94 ; \mathrm{p}<0.01)$ which indicates that the more complex the client's operations, the more the audit work, and the higher the audit fees. Previous findings on firm complexity and audit pricing are often divergent. But this study supports the previous evidence as in Silva et al, 2020; Januarti et al., 2019 and Urhoghide and Izedonmi, 2015. We believe our findings may be more conclusive given our sample. 
Hypothesis 12 (Foreign Operations) reveals a negative and significant relationship between foreign operations and audit fees $(\mathrm{t}=-2.81 ; \mathrm{p}>0.01)$, contrary to our expectations. However, it supports the recent findings of Hoffman et al. (2018). This negative relationship can be due to a variety of reasons such as outsourcing of foreign work, global shift to International Financial Reporting Standards (IFRS) and online and remote auditing. This may be a useful future research area.

\section{Conclusion}

The determinants of audit fees have been extensively investigated in the prior literature. As the previous results indicate, multiple factors determine audit fees. However, prior results are conflicting and inconsistent. The economy, market and country-specific factors do influence audit fees in different, often contradictory, ways. To address these inconsistencies, we developed a comprehensive model after a detailed study of the literature. We found that the most critical factors which have a significant positive influence on audit fees are client size, leverage (risk), profitability, complexity, losses, AC independence (non-executive members), AC expertise and auditor size. These factors hold across a range of industries and countries.

Additionally, the study shows that audit pricing is significantly negatively related to foreign operations, auditor tenure and internal audit independence. On the other hand, no significant relationship was found between the existence of audit boards and audit fees. Hence, our results are mostly in line with the prior evidence. We do find strong relationships among most of the variables. Out of the twelve hypotheses tested in this study, ten support the prior studies and one does not. The $\mathrm{R}$ square for the entire model equals $34,33 \%$, thus it has good explanatory power. Additionally, our results cover a more recent period, across a large number of countries and multiple industries, providing more robust results.

The model developed in this study should be useful for auditors, corporations and regulators. The auditors can develop a better insight into the factors that influence audit fees allowing them to price the audits more accurately. The corporations can understand the reasoning behind the audit fees. The results also highlight the importance of ACs. This may motivate regulators to enforce appropriate governance practices for the listed companies, especially the independence and expertise findings for ACs and internal audit function.

Future research may investigate additional factors that influence $\mathrm{AC}$ diligence and the impact of emerging technologies on remote auditing, as it is a new reality in the age of pandemics. This situation may have affected the fair values of a firm's tangible and intangible assets and also the income stream. Such pandemic effects may interact with the findings in this study and may provide a fertile research area in the coming years. Additionally, factors such as internal audit costs and industry specialization may also be examined in future studies. Finally, it will be interesting to examine how ownership concentration, family ownership and foreign ownership affect the audit fees, within different institutional setups.

\section{References}

Abbott, L. J., Parker, S., Peters, G. F., and Raghunandan, K., (2003). Association between audit committee characteristics and audit fees, Auditing: A Journal of Practice and Theory, 22(2), 17-32.

Agoes, S., (2004). Auditing (Accountants' examination) by Public Accounting Firm, 1, 3rd ed., Jakarta: University of Indonesia.

Al-Hajaya, K., (2019). The impact of audit committee effectiveness on audit quality: Evidence from the Middle East, International Review of Management and Marketing, 9(5), 1-8.

Ali, S., and Aulia, M., (2015). Audit firm size, auditor industry specialization, and audit quality: an empirical study of Indonesian state-owned enterprises, Research Journal of Finance and Accounting, 6 (22), 1-14.

Alzeban, A., and Sawan, N., (2015). The impact of audit committee characteristics on the implementation of internal audit recommendations. Journal of International Accounting, Auditing, and Taxation, 24 (1), 61-71.

Andriyani, B dan Laksito, H., (2017). Analisis Pengaruh Struktur Kepemilikan Perusahaan terhadap Biaya Audit, Diponegoro Journal of Accounting, 6(3), $1-11$

Azmi, N.A., Zakaria, N.B., and Yusoff, M. Atef Md., (2013). Audit committee attributes on audit fees: The impact of Malaysian Code of Corporate Governance (MCCG) 2007, Journal of Modern Accounting and Auditing, 9 (11), 1442-1453.

Bala, H., Amran, N.A., and Shaari, H., (2018). The relationship between audit committee attributes and audit fees of listed companies in Nigeria, The Social Science Journal, Special Issue, (6), 402408 .

Barua, A., Hossain, M.S., and Rama, D.V., (2019). Financial versus operating liability leverage and audit fees, International Journal of Auditing, 23(2), 231-244.

Beshkooh, M., Soumehsaraei, B.G., Mahmoudi, V., and Kazemtabriz, F., (2013) The relationship between audit quality and agency cost, Journal of Basic and Applied Scientific Research, 3(2), 516-525.

Burrowes, A., and Hendricks, A., (2005). Independent financial experts: From wished for to wistful thinking, Managerial Finance, 31(9), 52-62.

Carcello, J.V., Hermanson, D.R., Neal, T.L., and Riley Jr, R.A., (2002). Board characteristics and audit fees, Contemporary Accounting Research, 19 (3), 365-384. 
Carey, P., R. Simnett, and G. Tanewski, (2000). Voluntary demand for internal and external auditing by family businesses, Auditing: A Journal of Practice and Theory 19 (Supplement), $37-51$.

Castro, W., Peleias, I., and Silva, G., (2015). Determinants of audit fees: A study in the companies listed on the BM and FBOVESPA, Revista Contabilidade and Finanças, 26 (.69). Retrieved on 6 February 2020 from: https://www.scielo.br/scielo.php?script=sci_arttex tandpid=S1519. 70772015000300261 andlng $=$ ptandtlng=pt.

Choi, Jong-Hag, Kim, Francis, Kim, Jeong-Bon, and Zang, Yoonseok., (2010). Audit office size, audit quality, and audit pricing. Auditing: A Journal of Practice and Theory. 29, (1), 73-97.

Collier, P., and Gregory, A., (1996). Audit Committee Effectiveness and the Audit Fee, European Accounting Review, 5, 177-198, https://doi.org/10.1080/09638189600000012

DeAngelo, L., (1981). Auditor size and audit quality, Journal of Accounting and Economics, 3(3), 183199.

Dekeyser, S., Gaeremynck, A., and Willekens, M. (2019). Evidence of industry scale effects on audit hours, billing rates, and pricing. Contemporary Accounting Research, 36(2), 666693.

Dinh, H. T. V., (2012). Determinants of audit fees for Swedish listed non-financial firms in NASDAQ OMX Stockholm, M.Sc. Thesis, Department of Business Administration. School of Economics and Management. LUND University.

El-Gammal, W., (2010). Determinants of audit fees: Evidence from Lebanon, International Business Research, 5 (11), 136-145.

Fafatas, S.A., and Sun, K.J., (2010). The relationship between auditor size and audit fees: Further evidence from big four market shares in emerging economies, Research in Accounting in Emerging Economies, 1, 57-85.

Felix, W.L. Jr, Gramling, A., and Maletta, M., (2001). The contribution of internal audit as a determinant of external audit fees and factors influencing this contribution, Journal of Accounting Research, 39(3), 513-30.

Galani, D., Alexandridis, A., and Stavropoulos, A., (2011). The association between the firm characteristics and corporate mandatory disclosure: The case of Greece, World Academy of Science. Engineering and Technology, 77, 101-107.
Ghafran, C., and O'Sullivan, N., (2017). The impact of audit committee expertise on audit quality: Evidence from UK audit fees, British Accounting Review, 49 (6), 578-593.

Goodwin-Stewart, J., and Kent, P., (2006). Relation between external audit fees, audit committee characteristics and internal audit, Accounting and Finance. 46(3), 387-404.

Hackenbrack, K., and Knechel, W. R., (1997). Resource Allocation Decisions in Audit Engagements, Contemporary Accounting Research, 14, 481500

Hallak, R. T. P., and Silva, A. L. C., (2012). Determinants das despesas com serviços de auditoria e consultoria prestados pelo auditor independente no Brasil. Revista Contabilidade and Finanças, 23(60), 223-231.

Haniffa, R. and Cooke, T.E. (2002). Culture, corporate governance and disclosure in Malaysian corporations, Abacus, 38 (3), 317-349.

Haque, T., Afroze, S., and Tuz-Zohra, F., (2019). Impact of corporate governance on audit fees and audit quality: A Study in insurance industry in Bangladesh, The Cost and Management, 47(2), 411.

Harris, Cindy K., (2007). The Association Between Corporate Governance and Audit Fees, (2007). Business and Economics Faculty Publications, 32 ,

https://digitalcommons.ursinus.edu/bus_econ_fac 132 .

Hay, D.C., Knechel, W.R. and Wong, N., (2006). Audit fee: A meta-analysis of the effect of supply and demand attributes, Contemporary Accounting Research, 23 (1), 141-191.

Ho, S., and Hutchinson, M., (2010). Internal Audit Department Characteristics/Activities and Audit Fees: Some Evidence from Hong Kong Firms, Journal of International Accounting, Auditing and Taxation, 19(2), 121-136.

Hoffman, B.W., Sellers, R.D., and Skomra, J., (2018). The impact of client information technology capability on audit pricing, International Journal of Accounting Information Systems, 29, 59-75.

Hossain, M.N., and Sobhan, R., (2019). Determinants of audit fees: Evidence from pharmaceutical and chemical industry of Bangladesh. International Journal of Trend in Scientific Research and Development, 4(1), 815-821.

Ittonen, K., and Peni, E., (2012). Auditor's gender and audit fees, International Journal of Auditing, 16(1), 1-18. 
Januarti, I., and Wiryaningrum, M.S., (2019). The effect of size, profitability, risk, complexity, and Independent audit committee on audit fee, JDA Jurnal Dinamika Akuntansi 10 (2), 136-145.

Joshi, P L., and Al-Bastaki, H., (2000). Determinants of audit fees: Evidence from the companies listed in Bahrain, International Journal of Auditing, 4 (2), 129-138.

Judge, G.G., Griffiths, W.E., Hill, R.C., Lütkepohl, H., and Lee, T-C., (1985). The theory and practice of econometrics, 2nd ed., New York: John Wiley and Sons.

Kanakriyah, R., (2020). Model to determine main factors used to measure audit fees, Academy of Accounting and Financial Studies Journal, 24 (2), $1-13$.

Kikhia, K.Y., (2015). Determinants of audit fees: Evidence from Jordan, Accounting and Finance Research, 4(1), 42-53.

Köhler, Annette G. and Ratzinger-Sakel, Nicole V.S., (2012). Audit and Non-Audit Fees in Germany The Impact of Audit Market Characteristics, Schmalenbach Business Review, 64, October, 281-307, https://ssrn.com/abstract=2183195.

Kwon, S.D., Lim, Y.D., and Simnett, R., (2014). Mandatory audit firm rotation and audit quality: Evidence from the Korean audit market. Auditing, Journal of Practice and Theory, 33(4), 167-196.

Lee, HY, and Mande, V. (2005). The relationship of audit committee characteristics with endogenously determined audit and non-audit fees, Quarterly Journal of Business and Economics, 44(3/4), 93-112.

Ling, G.P., (2014). The determinants of audit remuneration among listed manufacturing companies in Malaysia, Research project, Faculty of Business and Finance Department of Commerce and Accountancy, University Tunku Abdul Rahman.

Liu, S., (2017). An empirical study: Auditors' characteristics and audit fee, Open Journal of Accounting, 6(2), 52-70.

Malagila, J., Bhavani, G., and Tabi, C., (2020). The perceived association between audit rotation and audit quality: Evidence from the UAE. Journal of Accounting in Emerging Economies. ahead-ofprint. 10.1108/JAEE-08-2018-0082.

Messier, W. F., Reynolds, J. K., Simon, C. A., and Wood, D. A., (2011). The effect of using the internal audit function as a management training ground on the external auditor's reliance decision. The Accounting Review, 86 (6), 2131-2154.
Mustapha, A., Isiaka, A. O., and Babatunde, K. A. (2020). Audit committee effectiveness and audit fee among listed deposit money banks in Nigeria. Asian Journal of Economics, Business and Accounting, 20(4), 1-14.

Naser, K., and Hassan, Y. M., (2016). Factors influencing external audit fees of companies listed on Dubai Financial Market, International Journal of Islamic and Middle Eastern Finance and Management, 9(3), 346-363.

Naser, K., and Nuseibeh, R., (2008). Determinants of audit fees: Empirical evidence from an emerging economy, International Journal of Commerce and Management, 17(3), 239-254.

Olushola, F.K., Suleiman, M., and Olatunji, L., (2020). Does audit committee effectiveness affect external audit fees? Evidence from listed companies in Nigeria, International Journal of Scientific and Engineering Research 11 (10), 878890.

Prawitt, D.F., Sharp, N.Y., and Wood, D.A. (2011). Reconciling archival and experimental research: Does internal audit contribution affect the external audit fee? Behavioural Research in Accounting, 23(2), 187-206.

Rainsbury, E.A., Bradbury, M., and.Cahan, S.F., (2009). The impact of audit committee quality on financial reporting quality and audit fees, 5 (1), 20-33.

Sandra, W., and Patrick, P., (1996). The determinants of audit fees in Hong Kong: An empirical study. Asian Review of Accounting, 4(2), 32-50.

Schneider, A., (1985). The reliance of external auditors on the internal audit function, Journal of Accounting Research, 23(2), 911-19.

Sierra-Garcíaa, Ruiz-Barbadillob, E., and Orta-Pérezc, M., (2019). Analysis of the influence of the internal audit function on audit fees, Spanish Accounting Review, 22(1), 100-111.

Silva, A.S.V.C., Inácio, H.C., and Vieira, E., (2020). Determinants of audit fees for Portugal and Spain, Contaduríay Administració, 65 (4), 1-24.

Simunic, D., (1980). The pricing of audit services: Theory and evidence, Journal of Accounting Research, 18(1), 161-190.

Sobrinho, W., and Bortolon, P., (2016). Non-audit servies and auditor independence in an environment of low investor protection, Revista Universo Contábil. 107-128. 10.4270/ruc.2016430 
Tran, M.D., Phamb, T.L., Phanb,T.T.H., Hoangc. T.H.L., Dod, D.T., and Dinhb, T.K.X., (2019). Factors influencing independent audit fees: Multi-group analysis PLS-SEM and moderate model, Management Science Letters, 9 (10), 1599-1608.

Urhoghide, R, O., and Izedonmi, F.O.I., (2015). An empirical investigation of audit fee determinants in Nigeria, International Journal of Business and Social Research, 5(8). Retrieved on 3 February 2020 from: https://thejournalofbusiness.org/index.php/site/art icle/view/785.

Velte, P., and Loy, T.R., (2018). The impact of auditor rotation, audit firm rotation and non-audit services on earnings quality, audit quality and investor perceptions. A literature review, Journal of Governance and Regulation, 7(2), 74-90.

VulHag, A., and Leghari, M.K., (2015). Determinants of audit fee in Pakistan, Research Journal of Finance and Accounting, 6(9), 176-188.

Warrad, L., (2018). Audit partner tenure, audit quality, and audit fees: Evidence from Jordanian firms, International Journal of Humanities and Social Science 9(10),163-172.

Wu, X., (2012). Corporate governance and audit fees: Evidence from companies listed on the Shanghai Stock Exchange, China Journal of Accounting Research, 5(4), pp. 321-342.

Yatim, Kent, P., and Clarkson, P. (2006). Governance structure, ethnicity, and audit fees of Malaysian listed firms, Managerial Auditing Journal, 21(7), 757-782.

Zaman, M., and Sarens, G., (2013). Informal interactions between audit committees and internal audit functions: Exploratory evidence and directions for future research. Managerial Auditing Journal, 28(6), 495-51. 